\title{
Karakteristik Harmonisa Pada Sistem Daya Listrik Air Handling Unit (AHU) Industri Farmasi
}

\author{
Erwin Yusuf ${ }^{1}$, I Made Wiwit Kastawan ${ }^{1}$, Nadya Intan Pratiwi ${ }^{1}$ \\ ${ }^{1}$ Jurusan Teknik Konversi Energi, Politeknik Negeri Bandung \\ email : erwin.yusuf@polban.ac.id, wiwit.kastawan@polban.ac.id.
}

\begin{abstract}
Abstrak
Industri farmasi merupakan salah satu jenis industri yang banyak menggunakan beban non-linier, khususnya variable speed drive (VSD). VSD umum digunakan sebagai penggerak motor listrik untuk pompa, kompresor atau blower yang banyak digunakan dalam berbagai proses di industri farmasi. Namun perlu diperhatikan bahwa penggunaan VSD dapat membawa dampak buruk terhadap sistem daya listrik di industri bersangkutan. Salah satunya adalah permasalahan kualitas daya berupa munculnya harmonisa pada sistem daya listrik. Berdasarkan data pengukuran lapangan, harmonisa arus pada sistem distribusi daya listrik untuk unit AHU dari sebuah industri farmasi yang dipilih sebagai objek studi masih berada di bawah standar IEEE 519-1992. Nilai total harmonic distortion arus $\left(T H D_{i}\right)$ yang terukur mencapai kisaran 40\% - 50\% dengan harmonisa ke-5, ke-7 dan ke-11 merupakan orde-orde harmonisa yang dominan. Simulasi dengan perangkat lunak ETAP menunjukkan nilai THD sebesar 44,15\% dengan spektrum yang mirip dengan data pengukuran lapangan. Perbedaan antara nilai $T_{H} D_{i}$ yang berdasarkan pengukuran lapangan dan simulasi mencapai kisaran $3 \%$ saja. Hasil simulasi dapat memverifikasi hasil pengukuran lapangan.
\end{abstract}

Kata Kunci: $A H U$, harmonisa, pengukuran, simulasi,VSD.

\section{PENDAHULUAN}

Distorsi harmonisa merupakan salah satu bentuk permasalahan kualitas daya listrik. Distorsi harmonisa pada suatu sistem daya listrik disebabkan oleh adanya arus yang mengalir melalui beban non-linier yang menghasilkan gelombang arus pada sisi sumber dengan bentuk non-sinusoidal [1]-[3]. Beban-beban non-linier ini dapat berupa peralatan seperti PC (personal computer), sumber daya listrik (power supply) atau UPS (uninterruptable power supply), lampu LED (light emitting diode), VSD untuk penggerak motor listrik dan lain sebagainya.

Untuk sektor industri, jenis beban non-linier yang berkontribusi besar terhadap distorsi harmonisa adalah sumber daya listrik searah/dc (direct current) dan VSD. VSD merupakan perangkat daya listrik yang lazim digunakan sebagai penggerak motor listrik pada pompa, kompresor dan blower karena mampu mengurangi penggunaan energi listrik secara signifikan [4]-[6]. VSD ataupun sumber daya listrik de pada dasarnya merupakan perangkat daya listrik yang menggunakan penyearah dioda tiga-fasa pada sisi sumber atau masukannya. Kerja dari penyearah dioda tiga-fasa inilah yang sejatinya mengakibatkan munculnya gelombang arus non-sinusoidal yang memiliki kandungan harmonisa tinggi yang diindikasikan oleh tingginya nilai THD [8].

Munculnya harmonisa dalam sistem daya listrik akan mengakibatkan beberapa kerugian. Kerugiankerugian tersebut antara lain adalah timbulnya derau (noise) elektromagnetik, pemanasan lebih pada mesin listrik yang dapat mengakibatkan peralatan produksi tidak bekerja secara optimal, gagalnya kerja sistem proteksi dan meningkatnya rugi-rugi saluran akibat meningkatnya arus saluran. Dalam jangka panjang berbagai dampak buruk akibat harmonisa ini akan mengurangi umur teknis peralatan seperti komputer, transformator, motor, dan kabel penghantar daya listrik. Umur teknis peralatan, yang berkurang tidak sesuai dengan jangka waktu pemakaian yang semestinya, mengakibatkan perusahaan harus mengeluarkan biaya tambahan cukup besar di waktu yang tidak tepat. Biaya tambahan tersebut digunakan untuk membeli juga memasang peralatan produksi yang baru, dimana hal 
tersebut mengakibatkan kerugian secara materil bagi industri [7].

\section{AHU PADA INDUSTRI FARMASI}

Industri farmasi merupakan kelompok industri yang teregulasi secara ketat (highly regulated industry) bermakna bahwa sistem utilitas di dalamnya diatur secara ketat guna memenuhi ketentuan cara-cara pembuatan obat yang baik (COPB). Sistem tata udara adalah salah satu diantaranya. Sistem tata udara, dikenal juga dengan istilah sistem HVAC (heating, ventilating and air conditioning) atau AHU (air handling unit) memegang peranan yang sangat penting dalam industri farmasi karena sistem tata udara yang baik dan benar akan dapat menjamin bahwa proses produksi obat dilakukan dengan baik (sesuai CPOB) serta memberi perlindungan terhadap lingkungan kerja dan karyawan.

AHU adalah cerminan penerapan CPOB dimana AHU merupakan salah satu sarana penunjang fundamental yang menjadi pembeda antara industri farmasi dengan industri lainnya. Sistem AHU membutuhkan sumber daya listrik agar dapat beroperasi karena sebagian besar komponen dari sistem AHU digerakkan oleh mesin/motor listrik. Pada salah satu industri farmasi yang dipilih sebagai objek penelitian, terdapat total sebanyak 24 unit AHU dengan kapasitas berbeda-beda. Komponen utama dari setiap unit AHU adalah sebuah static pressure fan (blower) dan sebuah kompresor. Komponen tambahan lainnya antara lain supply air fan, exhaust air fan dan fan filter yang juga membutuhkan suplai daya listrik untuk beroperasi. Beberapa unit AHU ada yang memiliki dua buah kompresor sehingga secara keseluruhan AHU di industry farmasi ini memiliki 29 buah kompresor dan 29 buah blower.

Kebutuhan daya listrik untuk seluruh unit AHU tersebut di atas diperoleh melalui sebuah MDP (main distribution panel) dan sebuah SDP (sub distribution panel). MDP dan SDP ini hanya digunakan untuk menyalurkan daya listrik ke unit AHU saja dan tidak melayani kebutuhan daya listrik untuk jenis beban yang lainnya. Pada SDP, unit-unit AHU ini dikelompokkan ke dalam empat panel beban masingmasing $\mathrm{HVAC}_{1}, \mathrm{HVAC}_{2}, \mathrm{HVAC}_{3}$ dan $\mathrm{HVAC}_{4}$. Keempat panel beban ini mensuplai daya listrik ke unit-unit AHU melalui sistem ac tiga-fasa dengan tegangan dan frekuensi konstan $400 \mathrm{~V}, 50 \mathrm{~Hz}$. Sistem suplai daya listrik ac tiga-fasa ini utamanya digunakan untuk menggerakkan motor listrik pada kompresor dan blower dari setiap unit AHU. Agar kecepatan motor listrik pada kompresor dan blower unit AHU dapat diatur maka sistem suplai daya listrik ac tiga-fasa dari panel beban akan digunakan terlebih dahulu untuk mensuplai unit VSD. Unit VSD akan mengkonversi suplai daya listrik ac tiga-fasa menjadi daya listrik ac tiga-fasa dengan tegangan dan frekuensi variabel untuk selanjutnya digunakan oleh motor listrik pada kompresor dan blower yang akan diatur kecepatan putarannya.

VSD pada dasarnya merupakan sebuah perangkat daya listrik yang terbentuk dari tiga buah konverter yaitu penyearah tiga-fasa di sisi masukan, regulator tegangan dc dan inverter tiga-fasa di sisi keluarannya. Jenis VSD yang lainnya menggunakan penyearah satufasa, alih-alih penyearah tiga-fasa, di sisi masukan. Namun untuk aplikasi di sektor industri VSD dengan penyearah tiga-fasa di sisi masukan lebih umum digunakan [9]. Dengan adanya penyearah tiga-fasa di sisi masukan maka gelombang arus di sisi masukan atau sisi sumber ac dari VSD akan mirip dengan gelombang arus sumber ac dari penyearah tiga-fasa. Gambar 1 dan Gambar 2 di bawah ini menunjukkan struktur dan bentuk gelombang arus sumber untuk fasa $R\left(i_{R}\right)$ dari penyearah tiga-fasa. Bentuk gelombang arus untuk kedua buah fasa lainnya, $S$ dan $T$, memiliki bentuk yang sama dengan gelombang arus fasa $R$ tetapi bergeser fasa $120^{\circ}$ dan $240^{\circ}$ [10].
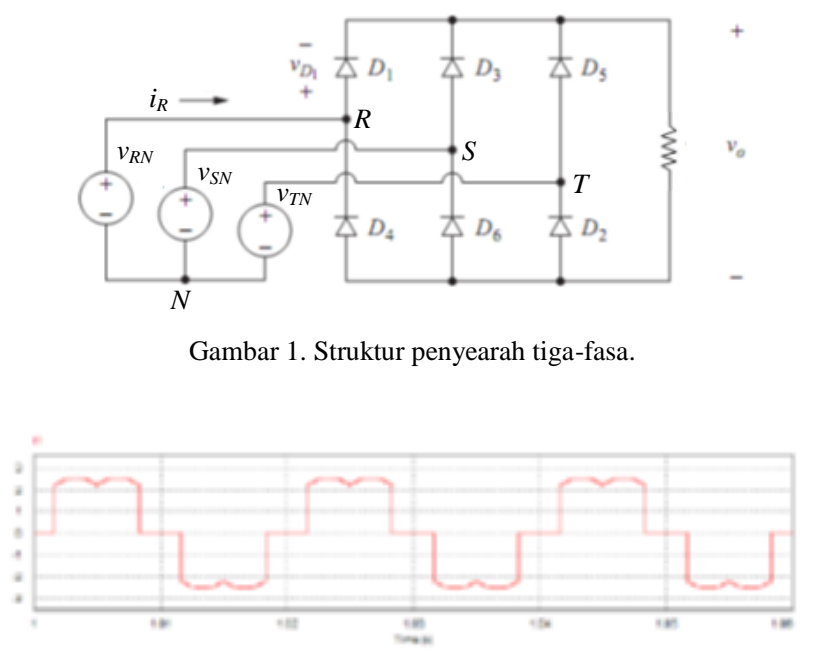

Gambar 2. Gelombang arus sumber (fasa $R$ ) penyearah tiga-fasa.

Spektrum harmonisa untuk gelombang arus sumber penyearah tiga-fasa ini ditunjukkan oleh Gambar 3. Dapat dilihat bahwa harmonisa yang dibangkitkan merupakan orde ganjil selain kelipatan tiga dengan harmonisa orde ke-5 dan ke-7 merupakan harmonisa 
yang dominan. Semakin tinggi orde harmonisanya maka akan semakin kecil magnitudanya. Dengan kata lain, semakin tinggi ordenya, semakin tidak dominan harmonisanya [11].

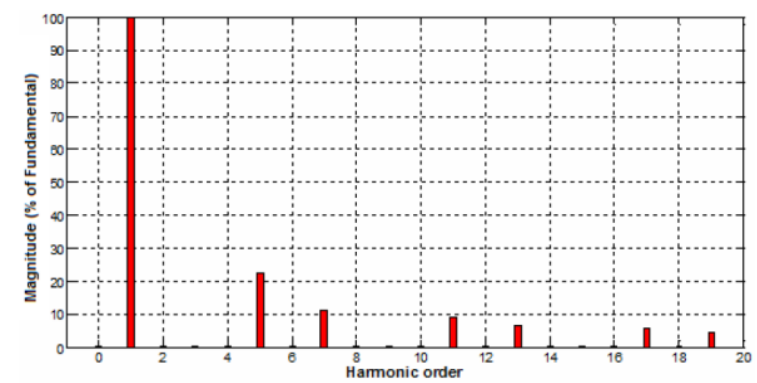

Gambar 3. Spektrum harmonisa gelombang arus sumber (fasa $R$ ) penyearah tiga-fasa.

\section{METODOLOGI}

Paper ini secara umum memuat uraian dan kajian mengenai permasalahan kualitas daya berupa harmonisa pada sistem daya listrik yang digunakan untuk mensuplai unit-unit AHU dari suatu industri farmasi yang dipilih sebagai objek studi. Telah diuraikan sebelumnya bahwa pada unit-unit AHU ini banyak digunakan beban non-linier berupa VSD untuk penggerak motor listrik kompresor dan blower. Selain itu, dijelaskan pula bahwa daya listrik untuk unit-unit AHU ini disuplai melalui sebuah MDP dan sebuah SDP khusus yang tidak digunakan untuk mensuplai beban listrik yang lain. Dari SDP, unit-unit AHU ini disuplai kebutuhan daya listriknya melalui empat buah panel beban yaitu $\mathrm{HVAC}_{1}, \mathrm{HVAC}_{2}, \mathrm{HVAC}_{3}$ dan $\mathrm{HVAC}_{4}$. Berdasarkan uraian ini maka langkah-langkah kajian terkait karakteristik harmonisa dari unit-unit AHU ini akan didahului dengan pengukuran lapangan menggunakan Power Quality (PQ) Analyzer dari setiap unit AHU yang terdapat pada sebuah panel beban yang dipilih saja yaitu $\mathrm{HVAC}_{3}$. Gambar 4 di bawah, menunjukkan titik-titik pengukuran lapangan yang dilakukan. Hasil pengukuran lapangan ini selanjutnya dibandingkan dengan hasil simulasi dengan perangkat lunak ETAP.

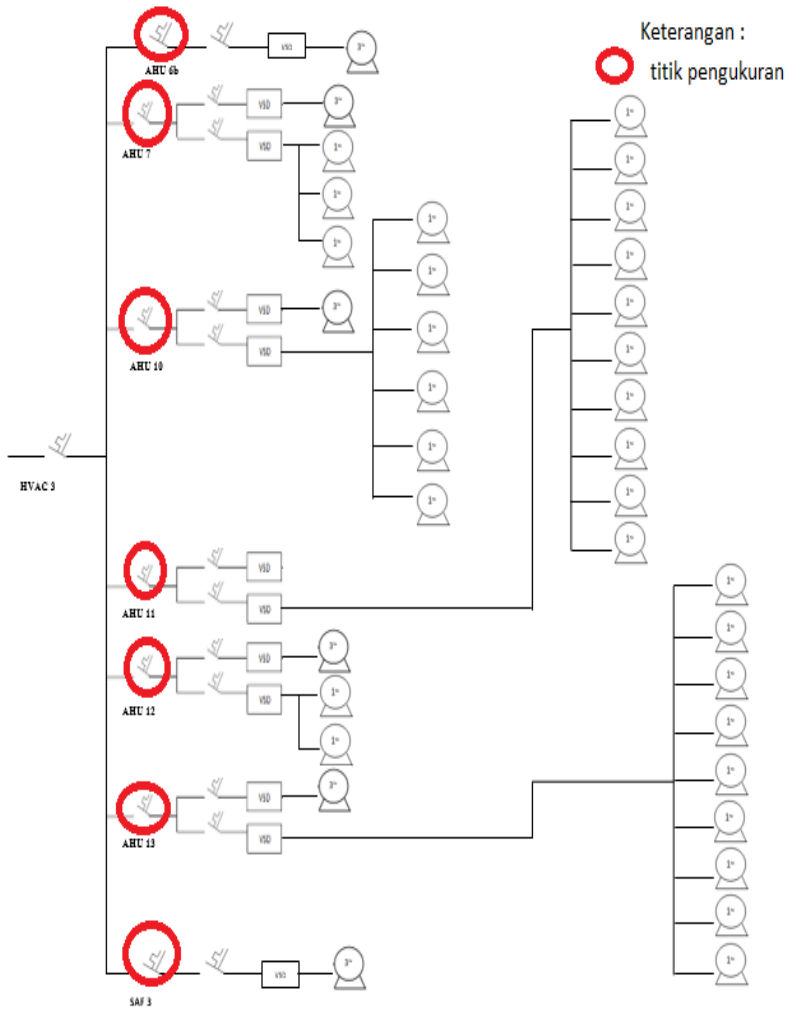

Gambar 4. Titik-titik pengukuran harmonisa pada panel beban.

\section{HASIL DAN PEMBAHASAN}

\section{A. Data Pengukuran Lapangan}

Berdasarkan data pengukuran lapangan dapat diketahui bahwa harmonisa arus pada sistem daya listrik AHU di industri farmasi yang dipilih sebagai objek studi masih berada di bawah standar IEEE 5191992 "IEEE Recommended Practices and Requirements for Harmonic Control in Electrical Power Systems". Distorsi harmonisa ini utamanya terjadi pada beberapa unit AHU yang terhubung ke panel beban $\mathrm{HVAC}_{3}$ yaitu AHU 6A, AHU 6B, AHU 9, dan AHU 11. Besarnya harmonisa arus yang terukur pada unit-unit AHU ini adalah antara 40\% - 50\%. Untuk kajian karakteristik harmonisa, dari keempat unit AHU yang memiliki masalah distorsi harmonisa tersebut di atas dipilih AHU 6A dengan pertimbangan bahwa unit AHU ini menghasilkan harmonisa arus yang yang lebih besar atau signifikan dibandingkan unit-unit AHU lainnya.

Tabel 1 di bawah ini menampilkan data pengukuran lapangan nilai THD tegangan $\left(\mathrm{THD}_{\mathrm{v}}\right)$ dan arus $\left(\mathrm{THD}_{\mathrm{i}}\right)$ untuk masing-masing fasa dari suplai daya listrik tigafasa yang digunakan untuk memenuhi kebutuhan daya listrik unit AHU 6A. Pengukuran nilai $\mathrm{THD}_{\mathrm{v}}$ dan $\mathrm{THD}_{\mathrm{i}}$ 
ini dilakukan selama lima hari dan kemudian diambil nilai rata-ratanya. Adapun bentuk gelombang tegangan dan arus tiga-fasanya ditunjukkan oleh Gambar 5 di bawah.

TABEL 1.

DATA HASIl PENGUKURAN LAPANGAN THD VAN THD $_{\text {I }}$ Di PANEL BEBAN UNIT AHU 6A.

\begin{tabular}{rccccccr}
\hline Hari pengukuran & ke-1 & ke-2 & ke-3 & ke-4 & ke-5 & Rata-rata \\
\hline & $V_{R}$ & 1,435 & 1,421 & 1,405 & 1,389 & 1,350 & 1,400 \\
& $V_{S}$ & 1,428 & 1,415 & 1,402 & 1,398 & 1,210 & 1,371 \\
\multirow{4}{*}{ THD (\%) } & $V_{T}$ & 1,400 & 1,382 & 1,358 & 1,321 & 1,308 & 1,354 \\
& $I_{R}$ & 44,730 & 44,280 & 43,560 & 42,500 & 41,660 & 43,346 \\
& $I_{S}$ & 43,700 & 42,500 & 41,800 & 40,230 & 39,800 & 41,606 \\
& $I_{T}$ & 44,730 & 44,440 & 43,900 & 42,800 & 42,500 & 43,674
\end{tabular}

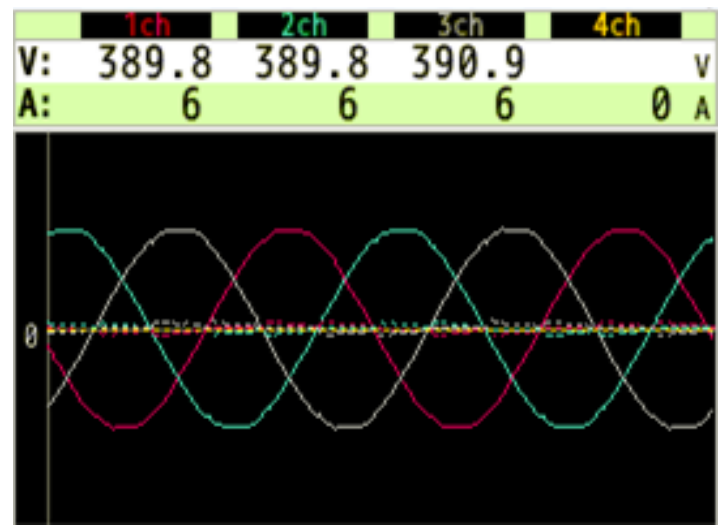

Gambar 5. Gelombang tegangan dan arus pada unit AHU 6A berdasarkan hasil pengukuran lapangan.

Dari Gambar 5 terlihat bahwa gelombang tegangan ac tiga-fasa untuk masukan unit AHU 6A mengalami distorsi yang disebabkan oleh terdistorsinya gelombang arus sebagai akibat penggunaan beban non-linier yang berupa VSD. Arus yang terdistorsi ini akan mengalir melewati impedansi linier sistem distribusi daya listrik sehingga mengakibatkan terdistorsinya gelombang tegangan sistem. Meskipun tidak terlihat dengan cukup jelas pada Gambar 5, gelombang arus sumber ac tigafasa yang terdistorsi dapat diketahui berdasarkan spketrum harmonisanya yang ditunjukkan oleh Gambar Gambar 6. Pada Gambar 6 ditunjukkan dengan jelas bahwa gelombang arus sumber tiga-fasa yang terukur memiliki $\mathrm{THD}_{\mathrm{i}}$ rata-rata sebesar 39,3\%. Terlihat juga bahwa komponen harmonisa yang dibangkitkan adalah orde ganjil selain kelipatan tiga dengan komponen harmonisa yang dominan adalah orde ke-5, ke-7, ke-11 dan ke-13. Data pengukuran lapangan ini sesuai atau mirip dengan karakteristik harmonisa dari konverter ac/dc atau penyearah tiga-fasa sebagai komponen utama pada sisi masukan VSD yang telah dibahas sebelumnya.

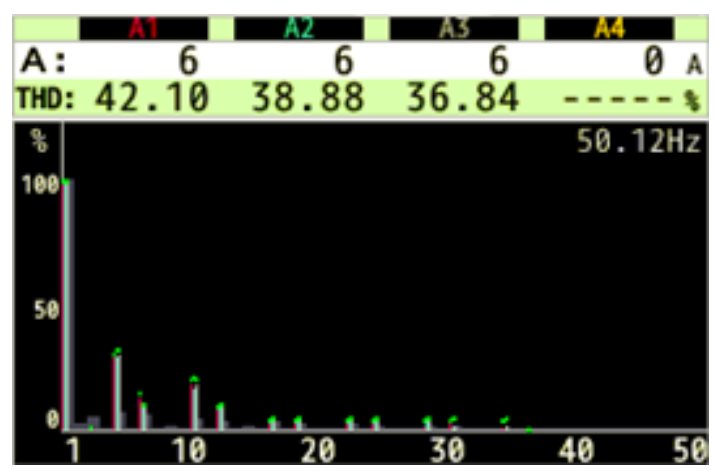

Gambar 6. Spektrum harmonisa arus pada unit AHU 6A berdasarkan hasil pengukuran lapangan.

\section{B. Data Simulasi}

Langkah simulasi dilakukan untuk memverifikasi data hasil pengukuran lapangan. Perangkat lunak yang digunakan untuk menyimulasikan karakteristik harmonisa unit AHU ini adalah ETAP (Electric Transient and Analysis Program). Gambar 7 di bawah menunjukkan single line diagram (SLD) untuk unit AHU 6A pada simulasi ETAP.

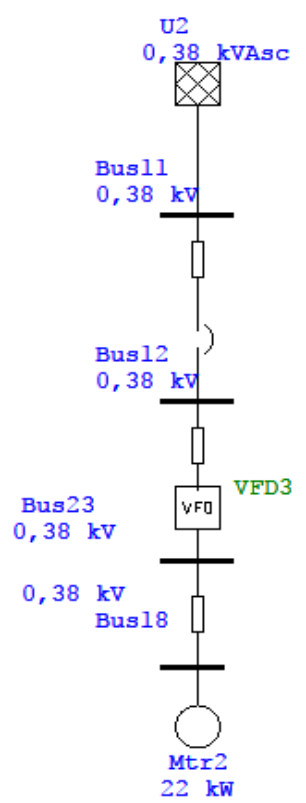

Gambar 7. Gambar single line diagram unit AHU 6A untuk simulasi

Setelah dilakukan penggambaran SLD unit AHU 6A seperti gambar di atas maka selanjutnya dilakukan 
langkah simulasi harmonic analyzer. Simulasi harmonic analyzer digunakan untuk mengetahui besar harmonisa arus yang seharusnya dihasilkan oleh beban non-linier yang terpasang. Simulasi harmonic analyzer dilakukan dengan menyesuaikan besar harmonisa arus berdasarkan data hasil pengukuran pada pengaturan rating dan harmonisa pada jenis beban yang digunakan. Pada simulasi ini akan dilakukan penyesuaian rating dan harmonisa pada VSD unit AHU 6A yang dimodelkan sebagai sumber harmonisa arus.

Hasil simulasi harmonic analyzer untuk unit AHU 6A ini ditunjukkan oleh Gambar 8 di bawah ini.

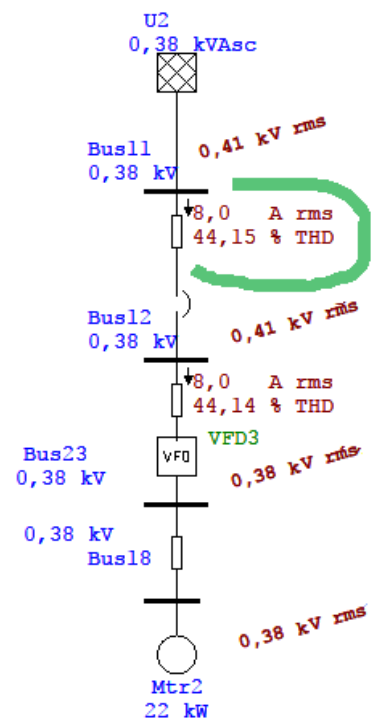

Gambar 8. Hasil simulasi harmonic analyzer pada unit AHU 6A.

Dari Gambar 8 terlihat bahwa nilai $\mathrm{THD}_{\mathrm{i}}$ yang dihasilkan adalah sebesar $44,15 \%$ pada bus 11 (bus utama ) dan 44,14\% pada bus 12 (bus yang terhubung langsung pada beban non-linier berupa VSD). Bus utama mengalami distorsi gelombang arus yang diakibatkan oleh penggunaan beban non-linier berupa VSD yang digunakan untuk mengontrol kecepatan motor ac tiga-fasa. Sementara itu spektrum harmonisa arus unit AHU 6A berdasarkan hasil simulasi ini dapat dilihat pada Gambar 9. Spektrum harmonisa ini kembali menunjukkan bahwa gelombang arus sumber tiga-fasa yang terdistorsi adalah terdiri dari komponen harmonisa orde ganjil selain kelipatan tiga dengan komponen harmonisa yang dominan adalah orde ke-5, ke-7, ke-11, ke-13, ke-17, ke-19, ke-23 dan ke-25. Data hasil simulasi cukup sesuai atau mirip dengan karakteristik harmonisa yang dibangkitkan VSD berdasarkan pengukuran lapangan serta karakteristik harmonisa dari konverter ac/dc atau penyearah tigafasa sebagai komponen utama pada sisi masukan VSD yang telah dibahas sebelumnya

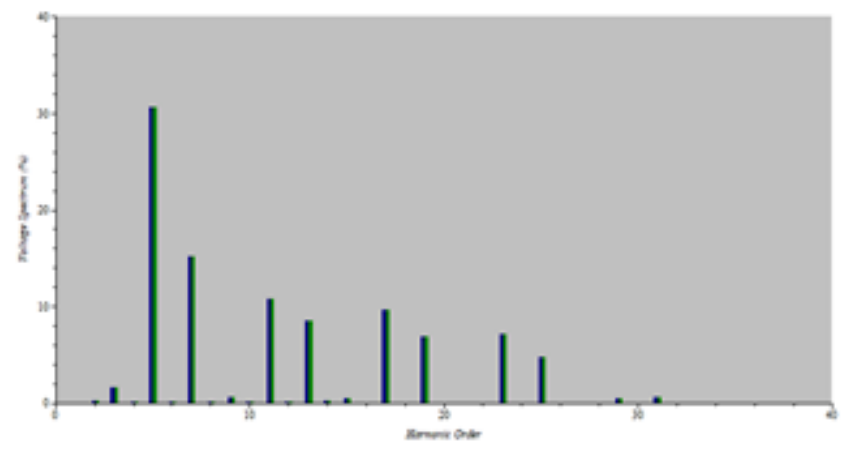

Gambar 9. Spektrum harmonisa arus pada unit AHU 6A berdasarkan hasil simulasi.

Adapun Gambar 10 menunjukkan hasil simulasi untuk gelombang arus terdistorsi pada unit AHU 6A yang diakibatkan oleh beban berupa motor ac tiga-fasa berkapasitas $22 \mathrm{~kW}$ (sesuai kapasitas motor di lapangan) yang kecepatan putarannya dikontrol melalui VSD. Dari Gambar 10 terlihat jelas bahwa arus yang dihasilkan oleh beban mengalami distorsi sebagai akibat dibangkitkannya harmonisa oleh beban nonlinier berupa VSD yang digunakan pada unit AHU 6A. Meskipun secara bentuk tidak sepenuhnya sama dengan arus terdistorsi yang dibangkitkan oleh penyearah ac tiga-fasa (Gambar 2) namun kedua arus terdistorsi ini secara spektrum memiliki komponenkomponen harmonisa yang sama (lihat dan bandingkan Gambar 9 dan Gambar 3). Hal ini dikarenakan pada simulasi tegangan ac tiga-fasa sistem daya listrik yang digunakan untuk mensuplai unit VSD juga ikut terdistorsi (terkonfirmasi juga melalui data pengukuran lapangan yang ditunjukkan oleh Tabel 1 dan Gambar 5). Arus yang terdistorsi ini akan mengalir melewati impedansi linear pada sistem distribusi sehingga mengakibatkan terdistorsinya juga tegangan ac tigafasa sistem daya listrik.

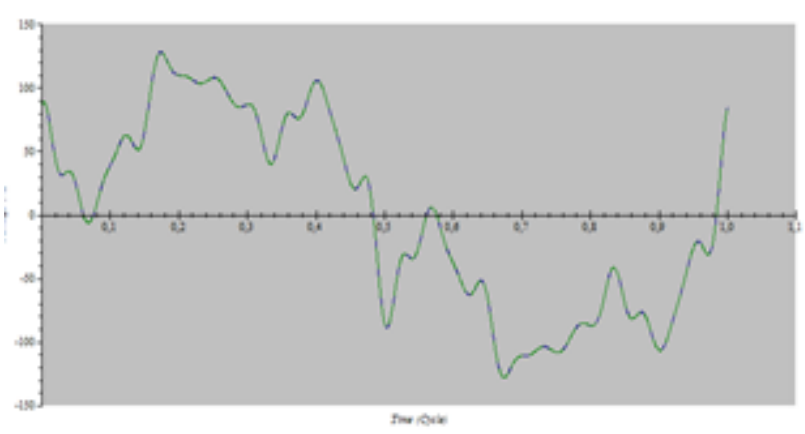


Gambar 10. Gelombang arus sinusoidal terdistorsi pada unit AHU 6A.

Untuk memverifikasi lebih lanjut karakteristik harmonisa yang dibangkitkan oleh unit AHU ini maka dilakukan perbandingan antara data pengukuran lapangan dan simulasi. Perbandingan dilakukan untuk parameter THD dan individual harmonic distortion (IHD). Tabel 2 di bawah ini menampilkan perbandingan yang dimaksud.

TABEL 2.

Perbandingan THD Dan IHD Hasil PengukuRan Dan Simulasi.

\begin{tabular}{ccccc}
\hline & & $\begin{array}{c}\text { Simulasi } \\
(\%)\end{array}$ & $\begin{array}{c}\text { Pengukuran } \\
(\%)\end{array}$ & $\begin{array}{c}\text { Kesalahan } \\
(\%)\end{array}$ \\
\hline THD & & 44,150 & 42,875 & 3 \\
\hline \multirow{6}{*}{ IHD } & ke-5 & 3,264 & 2,665 & 22 \\
& ke-7 & 1,112 & 0,989 & 12 \\
& ke-11 & 0,884 & 1,145 & 23 \\
& ke-13 & 0,256 & 0,385 & 34 \\
& ke-17 & 0,288 & 0,294 & 2 \\
& ke-19 & 0,176 & 0,194 & 9 \\
& ke-23 & 0,176 & 0,194 & 9 \\
& ke-25 & 0,112 & 0,194 & 42 \\
\hline
\end{tabular}

Tabel 2 menunjukkan perbandingan nilai THD $_{i}$ dan IHD arus $\left(\mathrm{IHD}_{\mathrm{i}}\right)$ yang diperoleh dari simulasi dan pengukuran lapangan. Dari tabel dapat dilihat bahwa terdapat selisih sebesar 3\% antara nilai THDi hasil simulasi dan pengukuran. Sementara itu, meskipun terdapat persentase selisih yang cukup besar antara IHDi hasil simulasi dan pengukuran lapangan, untuk orde ke-5 sebesar $22 \%$, orde ke- 7 sebesar $12 \%$, orde ke-11 sebesar $23 \%$, orde ke-13 sebesar $34 \%$ dan orde ke-25 sebesar $42 \%$, namun secara magnituda nilai sebenarnya cukup mendekati. Persentase selisih yang cukup besar dapat terjadi karena nilai-nilai yang dibandingkan merupakan nilai-nilai yang cukup kecil sehingga tidak tercakup dalam keakuratan alat ukur yang digunakan. Karena data pengukuran lapangan yang digunakan merupakan data dari unit AHU 6A maka $\mathrm{THD}_{\mathrm{i}}$ dan $\mathrm{IHD}_{\mathrm{i}}$ hasil simulasi secara umum dapat dikatakan mewakili dan memverifikasi karakteristik harmonisa pada unit AHU 6A.

\section{KESIMPULAN}

Berdasarkan data pengukuran lapangan dan simulasi telah dapat ditunjukkan bahwa penggunaan beban nonlinier yang berupa VSD pada unit AHU di industri farmasi akan mengakibatkan distorsi pada arus sumber ac tiga-fasa. Arus sumber yang terdistorsi ini memiliki kandungan harmonisa orde ganjil selain kelipatan tiga dengan harmonisa orde ke-5, ke-7, ke-11 dan ke-13 merupakan orde-orde yang cukup dominan. Karakteristik harmonisa arus sumber ini mirip dengan karakteristik harmonisa arus sumber penyearah ac tigafasa yang merupakan komponen utama pada sisi masukan VSD yang terhubung ke sumber ac tiga-fasa. Untuk kajian selanjutnya dapat dilakukan upaya untuk mengurangi distorsi arus sumber unit AHU ini misalnya dengan mendesain filter pasif untuk mengeliminasi orde-orde harmonisa dominan tersebut di atas atau dengan metode reduksi harmonisa lainnya.

\section{REFERENSI}

[1] A. Harrison, The Effect of Harmonic on Power Quality and Energy Efficiency, Dublin: Dublin Institute of Technology, 2010.

[2] R. Pinyol, Harmonics: Causes, Effects and Minimization, Barcelona: Salicru, 2015

[3] R. C. Dugan, M. F. McGranaghan, S. Santoso dan H. W. Beaty, Electrical Power System Quality, Third Edition, McGraw-Hill, 2012.

[4] S. Bambiso dan K. Kusakana, "Life Cycle Cost Comparison between Motor Equipped with Speed Drive and Dampers for Pumps and Pans,' dalam Conference Paper, 2018.

[5] S. Robak dan et. al, Variable Speed Drive (VSD) - Toward Modern Industry and Electricity Power System, Przeglad Elektrotechniczny, 2016.

[6] R. Saidur dan et. al., "Applications of Variable Speed Drive in Electrical Motor energy Savings," no. Renewable and Sustainalbe Energy Review, 2012

[7] I. M. W. Kastawan, E. Yusuf dan A. Fadhilah, "Simulation of Source Current Harmonic Elimination Technique using Phase Shifting Transformer," dalam ICIEVE, Bandung, 2019.

[8] Rashid, M. H. 2011. Power electronics handbook : devices, circuits, and applications, Third Edition ed., Burlington: Elsevier Inc.

[9] Toshiba. 2012. Industrial Inverter (For Three-Phase Induction Motor).

[10] Kastawan, I M. W. 2017. Reduksi Harmonisa Arus Sumber TigaFasa dengan Transformator Penggeser Fasa. Prosiding Seminar Nasional Teknoka 2, pp E-24-E-30. UHAMKA, Jakarta, INDONESIA

[11] Mahar, M. A. 2011. Harmonic Analysis of AC-DC Topologies and Their Impact on Power System. Jamshoro: Mehran University of Engineering and Technology 